\title{
Impact Resistance of Bendable Concrete Reinforced with Grids and Containing PVA Solution
}

\author{
Shrooq Abd Al Kareem \\ Department of Civil Engineering \\ College of Engineering \\ University of Baghdad \\ Baghdad, Iraq \\ s.shetan1901M@coeng.uobaghdad.edu.iq
}

\author{
Ikram Faraoun Ahmed \\ Department of Civil Engineering \\ College of Engineering \\ University of Baghdad \\ Baghdad, Iraq \\ ikram.faroun@coeng.uobaghdad.edu.iq
}

\begin{abstract}
The development of new building materials, able of absorbing more energy is an active research area. Engineering Cementitious Composite (ECC) is a class of super-elastic fiberreinforced cement composites characterized by high ductility and tight crack width control. The use of bendable concrete produced from Portland Limestone Cement (PLC) may lead to an interest in new concrete mixes. Impact results of bendable concrete reinforced with steel mesh and polymer fibers will provide data for the use of this concrete in areas subject to impact loading. The experimental part consisted of compressive strength and impact resistance tests along with a result comparison with unreinforced concrete. Concrete samples, with dimensions of $100 \times 100 \times 100 \mathrm{~mm}$ (cubes), and $500 \times 500 \times 50 \mathrm{~mm}$ (slabs), were poured and were treated at ages of 28, 56, and 90 days. The compressive strength increased by $36.11 \%, 45.5 \%$, and $52.4 \%$ respectively, whereas the impact resistance for samples reinforced with steel mesh and polypropylene fibers gave superior results to the conventional mixes.
\end{abstract}

Keywords-ECC concrete; impact resistance; polypropelene fiber

\section{INTRODUCTION}

In comparison with other building materials, concrete is more practical, durable, and economical [1]. Concrete is widely used as a building material due to its high durability, easy accessibility, and low cost [2] and is commonly used in almost every kind of construction [3]. Cracks are inevitable during the life of a concrete structure. Structures exposed to the external environment are more susceptible to cracking because they are affected by shrinkage or expansion in weight and drying in addition to other environmental conditions along with the overloading factor. These cracks affect the strength of the structures by weakening them and the mechanical properties and its durability are reduced as these cracks create a path for the penetration of harmful factors into the core of the structures [4]. Attempts have been made to reduce cracks and improve the tensile properties of concrete members by using traditionally reinforced steel bars and also through the application of restraining techniques. Although both methods provide more tensile strength to the concrete members, they do not increase the tensile strength of the concrete itself. In normal concrete and similar brittle materials, fine structural cracks develop even before loading due to drying shrinkage or other causes of volume changes. Upon loading, these micro cracks spread and open due to the stress concentration effect [5]. To give the concrete flexibility we have to modify the traditional material. This type of concrete is softer than conventional concrete and is known as the Engineered Cementitious Composite (ECC). Developed at the end of the twentieth century, the ECC demonstrates the unique properties of high strength concrete, including excellent stress-hardening properties, multiple cracking properties, and fiber bridging properties which in turn increase the ductility of a structure.

ECC, also called ultra-hard cementious composite, flexible concrete, or conflexpave, is a matrix-based composite material reinforced with short fibers with a maximum volume fraction of $2.0 \%$. ECC blends are generally developed by adding Polyvinyl Alcohol (PVA) solutions, Polypropylene (PP), and Polyethylene (PE) fibers. The introduction of fibers aims to reduce the damage in the concrete structure that is exposed to seismic and impact loads [6]. ECC concrete, is an easy-to-form mortar-based composite reinforced with specially selected short polymer fibers. ECC acts more like ductile metal than brittle glass which leads to a wide variety of applications. The tensile stress capacity of ECC can reach 3-5\%, which is much higher than the $0.01 \%$ of ordinary concrete. The compressive strength of ECC is similar to that of normal to high strength concrete. Ordinary concrete is brittle by nature while ECC is ductile. Due to this property, it has wide applications and future scopes in various fields [7]. The associated high fracture toughness and controlled slit width (typically less than $100 \mu \mathrm{m}$ ) make ECC an ideal material for improving the serviceability and durability of infrastructures [8].

\section{MATERIAL CHARACTERIZATION}

\section{A. Cement}

The cement employed in the current research was Ordinary Portland Cement (OPC) and Portland Limestone Cement (IL). The IL was produced by LAFARGE and conforms to European Standard EN-197-1 \& European Standard no 196-2-Type IL [9]. Tables I-IV show the properties and specifications of the two types of cement. 
TABLE I. PHYSICAL TESTS OF IL ACCORDING TO EUROPEAN STANDARD EN-197-1 FOR GRADE (42.5)

\begin{tabular}{|c|c|c|c|}
\hline Test & Test result & Specification limits & Compliance \\
\hline Finance (blain) $\mathrm{cm}^{2} / \mathrm{gm}$ & 5105 & At least & Matching \\
\hline $\begin{array}{c}\text { Initial setting time } \\
\text { (min) }\end{array}$ & $90 \mathrm{~min}$ & At least 45min & Matching \\
\hline \multicolumn{3}{|c|}{ Compressive strength (MPa) } \\
\hline 2days curing & 8 & At least (10-20) & Not matching \\
\hline 28 days curing & 34 & At least 42.5 & Not matching \\
\hline
\end{tabular}

TABLE II. CHEMICAL ANALYSIS OF IL ACCORDING TO EUROPEAN STANDARD NO 196-2

\begin{tabular}{|c|c|c|c|}
\hline $\begin{array}{c}\text { Oxides and } \\
\text { phases }\end{array}$ & $\begin{array}{c}\text { Karasta test } \\
\text { results (\%) }\end{array}$ & $\begin{array}{c}\text { Specification } \\
\text { limits }\end{array}$ & Compliance \\
\hline $\mathrm{CaO}$ & 62.22 & - & - \\
\hline $\mathrm{SiO}_{2}$ & 17.18 & - & \\
\hline $\mathrm{Al}_{2} \mathrm{O}_{3}$ & 4.19 & - & \\
\hline $\mathrm{Fe}_{2} \mathrm{O}_{3}$ & 2.91 & - & Not matching \\
\hline $\mathrm{MgO}_{\mathrm{SO}}$ & 1.95 & Not more than $5 \%$ & Not matching \\
\hline $\mathrm{LOI}$ & 2.44 & Not more than $2.5 \%$ & \\
\hline $\mathrm{Total}$ & 6.21 & Not more than $4 \%$ & Not matching \\
\hline $\mathrm{CI}-$ & 98.43 & - & \\
\hline $\mathrm{C}_{3} \mathrm{~A}$ & 0.011 & - & \\
\hline $\mathrm{I} . \mathrm{R}$ & 6.18 & Less than $0.1 \%$ & \\
\hline
\end{tabular}

TABLE III. CHEMICAL ANALY SIS OF OPC

\begin{tabular}{|c|c|c|}
\hline Oxide composition & Test results & $\begin{array}{c}\text { Limits of IQS } \\
\text { No.5 /2019 for OPC }\end{array}$ \\
\hline $\mathrm{CaO}$ & 62.32 & - \\
\hline $\mathrm{SiO}_{2}$ & 21.34 & - \\
\hline $\mathrm{Al}_{2} \mathrm{O}_{3}$ & 4.93 & - \\
\hline $\mathrm{Fe}_{2} \mathrm{O}_{3}$ & 5.43 & - \\
\hline $\mathrm{MgO}_{\mathrm{SO}_{3}}$ & 2.12 & $<5 \%$ \\
\hline $\mathrm{LOI}_{\mathrm{LSF}}$ & 2.35 & $<2.8 \%$ \\
\hline $\mathrm{IR}$ & 1.72 & $<4 \%$ \\
\hline $\mathbf{M a i n}$ Compounds (Bogue's equation) \\
\hline $\mathrm{C}_{3} \mathrm{~S}$ & 76.28 & - \\
\hline $\mathrm{C}_{2} \mathrm{~S}$ & 3.73 & - \\
\hline $\mathrm{C}_{3} \mathrm{~A}$ & 6.72 & - \\
\hline $\mathrm{C}_{4} \mathrm{AF}$ & 16.5 & - \\
\hline
\end{tabular}

TABLE IV. PHYSICAL TESTS OF OPC

\begin{tabular}{|c|c|c|}
\hline Physical properties & $\begin{array}{c}\text { Test } \\
\text { results }\end{array}$ & $\begin{array}{c}\text { Requirements of IQS } \\
\text { No.5/2019 for OPC }\end{array}$ \\
\hline $\begin{array}{c}\text { Specific surface area } \\
\text { (Blaine method) } \mathrm{m}^{2} / \mathrm{Kg}\end{array}$ & 376 & $>250$ \\
\hline Initial setting (h) & $2: 45$ & $>45 \mathrm{~min}$ \\
\hline Final setting (h) & $4: 20$ & $\leq 10 \mathrm{~h}$ \\
\hline $\begin{array}{c}\text { Soundness (autoclave } \\
\text { method) \% }\end{array}$ & 0.12 & $<0.8$ \\
\hline $\begin{array}{c}\text { Compressional strength } \\
\text { (MPa) at 2 days }\end{array}$ & 20 & $\geq 42.5$ \\
\hline $\begin{array}{c}\text { Compressional strength } \\
\text { (MPa) at 28 days }\end{array}$ & 37 & $\geq$ \\
\hline
\end{tabular}

\section{B. Sand}

Ekhaider natural sand was employed as fine aggregates in this study. Its physical and chemical properties are shown in Table V. Sieve analysis shows that the sand lies in Zone 2 from the tests that were carried according to the requirements of [10] as shown in Table VI.
TABLE V. PHYSICAL AND CHEMICAL TESTS OF FINE AGGREGATES

\begin{tabular}{|c|c|c|}
\hline Property & Test result & I.Q.S.45: 1984 limits \\
\hline Specific gravity & 2.6 & - \\
\hline Absorption \% & 0.72 & - \\
\hline Density $\left(\mathrm{kg} / \mathrm{m}^{3}\right)$ & 1580 & - \\
\hline $\mathrm{SO}_{3}$ & $0.2 \%$ & $0.50 \%$ (Max) \\
\hline
\end{tabular}

TABLE VI. GRADING TESTS OF FINE AGGREGATES

\begin{tabular}{|c|c|c|}
\hline Sieve no. & Passing \% & $\begin{array}{c}\text { Limits of Iraqi specification } \\
\text { no.45/1984 zone 2 }\end{array}$ \\
\hline $10 \mathrm{~mm}$ & 100 & 100 \\
\hline $4.75 \mathrm{~mm}$ & 93.3 & $100-90$ \\
\hline $2.36 \mathrm{~mm}$ & 77.7 & $100-75$ \\
\hline $1.18 \mathrm{~mm}$ & 66.6 & $90-55$ \\
\hline $600 \mu \mathrm{m}$ & 54.4 & $59-35$ \\
\hline $300 \mu \mathrm{m}$ & 26.3 & $30-8$ \\
\hline $150 \mu \mathrm{m}$ & 3.1 & $10-0$ \\
\hline
\end{tabular}

\section{Silica Fume}

Silica Fume (SF) (condensed micro-silica) with an activity index of $121 \%$ conforming to ASTM C1240-15 [11] was used. The technical data for the SF are shown in Tables VII and VIII.

TABLE VII. PHYSICAL TESTS OF SILICA FUME

\begin{tabular}{|c|c|c|}
\hline Physical properties & Silica fume & $\begin{array}{c}\text { Limit of specification } \\
\text { requirements ASTM C-1240 }\end{array}$ \\
\hline $\begin{array}{c}\text { Percent Retained on } 45 \mu \mathrm{m} \\
\text { (No. 325) sieve, Max.\% }\end{array}$ & 7 & $<10$ \\
\hline $\begin{array}{c}\text { Accelerated pozzolanic } \\
\text { strength activity Index } \\
\text { with Portland cement at 7 } \\
\text { days, Min. percent of } \\
\text { control }\end{array}$ & 121 & $>105$ \\
\hline $\begin{array}{c}\text { Specific surface, Min } \\
\left(\mathrm{m}^{2} / \mathrm{g}\right)\end{array}$ & 15 & $>15$ \\
\hline
\end{tabular}

TABLE VIII. CHEMICAL ANALYSIS OF SILICA FUME

\begin{tabular}{|c|c|c|c|}
\hline & $\mathbf{S i O}_{\mathbf{2}} \%$ & $\begin{array}{c}\text { Loss on } \\
\text { ignition \% }\end{array}$ & $\begin{array}{c}\text { Moisture } \\
\text { content \% }\end{array}$ \\
\hline Sample & 92.84 & 1.59 & 0.33 \\
\hline $\begin{array}{c}\text { Chemical requirement } \\
\text { according to ASTM- } \\
\mathrm{C} 1240-2012\end{array}$ & $85 \% \mathrm{~min}$ & $6 \% \max$ & $3 \%, \max$ \\
\hline
\end{tabular}

\section{Superplasticizer}

A third-generation superplasticizer (Sika Viscocrete -5930) was employed, which conforms to the specifications of ASTMC494 Types G and F [12]. Superplasticizers are employed to attain sever decrease of water, enhanced flowability, and optimal cohesion. The decrease in water-cement $(w / c)$ ratio means that the cement paste permeability reduces noticeably, hence superplasticizers can be effectively employed to enhance the properties of concrete and prevent specific defects such as honeycombing.

\section{E. Water}

Tap water was used conforming [13]

\section{F. Polypropylene Fibers}

PP fibers absorb water and resist alkalis, chemicals, and chloride. Table IX shows the properties of PP fibers. 


\section{TABLE IX. PROPERTIES OF PP FIBERS}

\begin{tabular}{|c|c|}
\hline Length & $12 \mathrm{~mm}$ \\
\hline Diameter & 0.032 \\
\hline Density $\mathbf{K g} / \mathbf{m}^{3}$ & 910 \\
\hline Tensile properties & $600-700$ \\
\hline
\end{tabular}

\section{G. Polyvinyl Alcohol (PVA) Solution}

PVA is a water-soluble and biodegradable artificial polymer. PVA is an excellent adhesive with superior bonding strength and film forming and emulsifying properties. It has excellent adhesion to both hydrophilic and hydrophobic materials. The solution was prepared to employ closely $80 \mathrm{~g}$ of PVC in 2lt of boiled water until it disappeared completely.

\section{H. Reinforcement Grids}

Two kinds of grid reinforcement were employed, steel and polymer with $12.7 \mathrm{~mm}$ square opening size and $0.2 \mathrm{~mm}$ diameter.

\section{EXPERIMENTAL WORK}

\section{A. Mixures}

Two major categories of ECC mixtures have been designed and chosen. The first mixture was composed of OPC, sand, SF, PVA solution, and the optimum dosage of superplasticizer of about $1.3 \%$ which is within the acceptable range which is between 0.2 and $1.5 \%$ by weight of cement. The mix was reinforced with PP fibers. The second mixture was composed of the same components except that it was produced from IL cement. The mix designs are described in detail in Table X.

TABLE X. MIX PROPORTIONS

\begin{tabular}{|c|c|c|c|}
\hline \multicolumn{2}{|l|}{ Type } & Ref. & ECC \\
\hline \multirow{2}{*}{ Cement $\left(\mathrm{kg} / \mathrm{m}^{3}\right)$} & OPC & \multirow{2}{*}{356} & \multirow{2}{*}{356} \\
\hline & $\mathrm{IL}$ & & \\
\hline Sand $\left(\mathrm{kg} / \mathrm{m}^{3}\right)$ & Zone 2 & 320 & 320 \\
\hline $\mathrm{SF}\left(\mathrm{kg} / \mathrm{m}^{3}\right)$ & - & 285 & 285 \\
\hline VF $\left(\mathrm{kg} / \mathrm{m}^{3}\right)$ & PPM & - & 18 \\
\hline Water $\left(\mathrm{kg} / \mathrm{m}^{3}\right)$ & - & 288 & 288 \\
\hline S.P $\left(\mathrm{kg} / \mathrm{m}^{3}\right)$ & 5930 & 4.6 & 4.6 \\
\hline Acetate $\left(\mathrm{kg} / \mathrm{m}^{3}\right)$ & PVA & - & 3.56 \\
\hline
\end{tabular}

\section{B. Molds Preparation}

For compressive strength tests, $100 \times 100 \times 100 \mathrm{~mm}$ cubes were used, and for the impact resistance test, $500 \times 500 \times 50 \mathrm{~mm}$ molds were used.

\section{RESULTS AND DISCUSSION}

\section{A. Compressive Strength}

The compressive strength test was conducted according to the British standard B.S.1881: part116 [14] by using 3 cubes specimens with dimensions of $100 \times 100 \times 100 \mathrm{~mm}$ and with a testing machine of $2000 \mathrm{KN}$ capacity with loading rate of $2.5 \mathrm{MPa} / \mathrm{s}$, at a position perpendicular to the direction of casting (Figure 1-2). The compressive strength test was conducted at the ages of 28,56 , and 90 days.

It can be noted that the samples reinforced with PP fibers have better results than the reference mixtures. The increase in compressive strength was $36.11 \%, 45.5 \%$, and $52.4 \%$ at 28,56 , and 90 days of water curing respectively. The difference between the two types of cement is the change in the chemical compounds of the cement The interpretation of the compressive strength test results is divided into three stages:

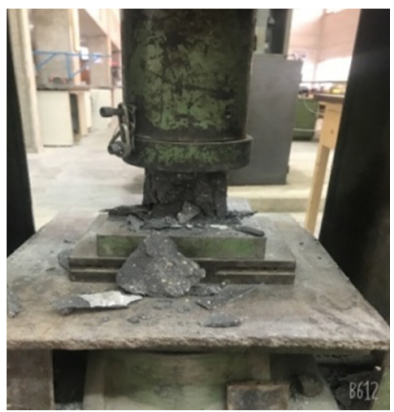

Fig. 1. The typical failure behavior of reference concrete specimens.

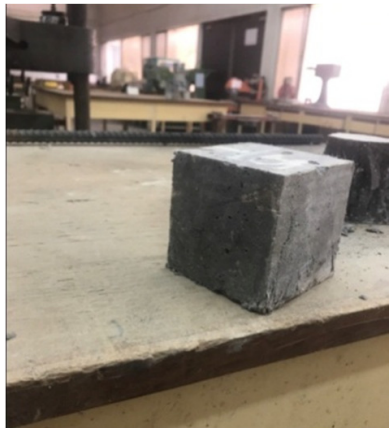

Fig. 2. The typical failure behavior of concrete specimens with $2 \%$ PP fibers under compression.

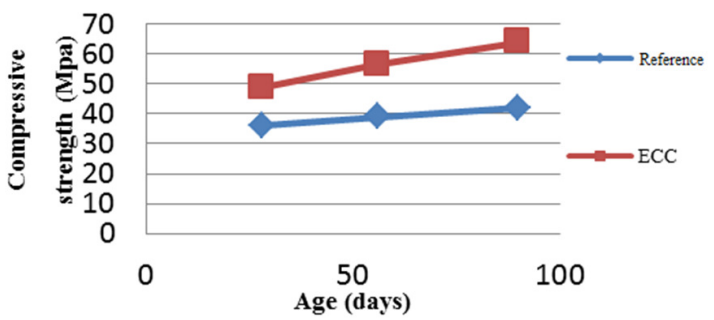

Fig. 3. Compressive strength vs curing age of mixes containing OPC.

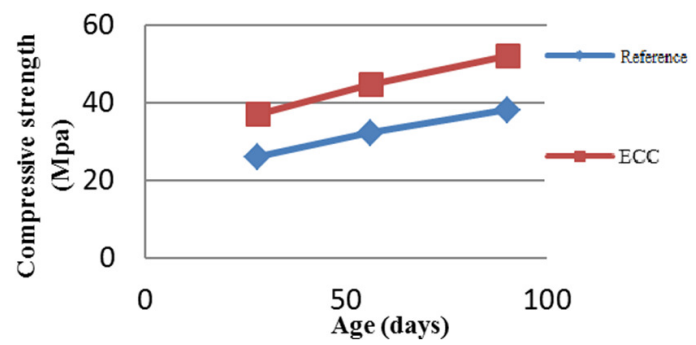

Fig. 4. Compressive strength vs curing age of mixes containing IL.

At first, there is the addition of PP fibers. These fibers were combined with the cement paste and enhanced the ability of micro cracks to spread without breaking or pulling the fibers and therefore reduced the cracks in the concrete. 
The second stage is the addition of small amounts of watersoluble polymers (PVA solution) that enhance the bonding strength and durability of cementing materials.

In the third stage, and keeping in mind the recent focus on the sustainable influence on unstable constructions, the environmentally friendly SF decreases carbon dioxide emissions by decreasing the amount of cement used. SF is a material with a volume twice smaller than cement, which can easily fill the voids between cement particles, and is also a highly active pozzolanic material that reacts easily with $\mathrm{Ca}(\mathrm{OH})_{2}$ and water to form secondary $\mathrm{CSH}$ through a pozzolanic reaction whereby the generated $\mathrm{CSH}$ fills the capillary voids and a denser microstructure and high compressive strength can be achieved (Figure 2). Timedependent deformation behavior of bendable concrete produced by IL cement was studied in [15]. Two types of IL cement were used and PP fibers and PVA solution were utilized. The best results obtained were for mixes containing PP fibers and PVA solution [15].

\section{B. Impact Resistance}

The device used to measure impact resistance contains three parts that can be described as follows:

- The main support part: It consists of an iron bracket that is strong enough to support the examination device during the examination and withstand the impact. It also contains another support on which the examination form is placed, which is of angle iron and is well fixed to prevent the movement of the form during the examination.

- The iron structure for dropping the block: It is a cylindrical tube with an inner diameter of $10.5 \mathrm{~cm}$. It is fixed with supports that prevent it from moving during the examination. This tube contains an opening of $1.5 \mathrm{~m}$ height.

- The falling block: It is an iron ball, weighing $3.4 \mathrm{~kg}$ with a diameter of $9.5 \mathrm{~cm}$. This mass is thrown from the height of $1.5 \mathrm{~m}$ on the model several times.

The model is placed on the supporting iron structure, and then the iron block is dropped from the specified height of $1.5 \mathrm{~m}$ on the model. The number of blows at which the first crack appears and the number of blows to cause failure were recoded. The average of three $50 \times 50 \times 5 \mathrm{~cm}$ specimens was considered. The test was carried out at the ages of 28,56 , and 90 days according to ACI C-544 [16]. The results are shown in Table XI.

TABLE XI. IMPACT RESISTANCE TEST RESULTS

\begin{tabular}{|c|c|c|c|c|c|c|c|}
\hline \multirow{2}{*}{ Mix } & \multirow{6}{*}{ Reinforcement } & \multicolumn{6}{|c|}{ Impact resistance } \\
\cline { 3 - 8 } & & \multicolumn{5}{|c|}{ No. of blows to cause: } \\
\cline { 3 - 8 } & & $\mathbf{1}^{\text {st }}$ crack at day & \multicolumn{2}{|c|}{ Failure at day } \\
\cline { 2 - 8 } & $\mathbf{2 8}$ & $\mathbf{5 6}$ & $\mathbf{9 0}$ & $\mathbf{2 8}$ & $\mathbf{5 6}$ & $\mathbf{9 0}$ \\
\hline Reference (OPC) & Plain & 2 & 4 & 6 & 3 & 5 & 6 \\
\hline \multirow{2}{*}{ ECC OPC } & Steel & 6 & 8 & 9 & 67 & 93 & 118 \\
\cline { 2 - 8 } & Polymer & 5 & 7 & 9 & 32 & 50 & 67 \\
\hline Reference (IL) & Plain & 2 & 4 & 5 & 3 & 5 & 6 \\
\hline \multirow{2}{*}{ ECC IL } & Steel & 5 & 7 & 8 & 50 & 53 & 55 \\
\cline { 2 - 8 } & Polymer & 5 & 7 & 8 & 23 & 31 & 38 \\
\hline
\end{tabular}

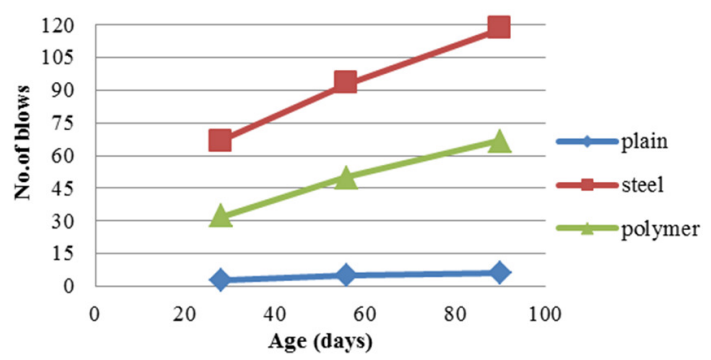

Fig. 5. Impact resistance with curing age of reference and ECC concrete mixes containing OPC.

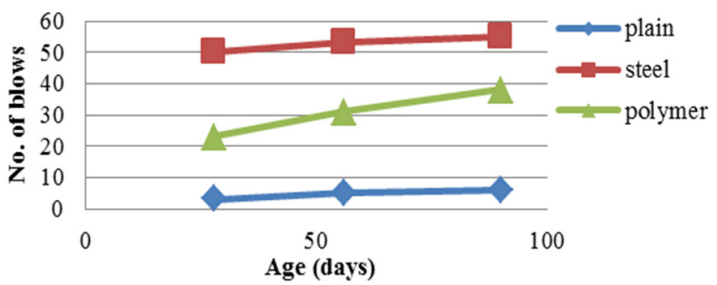

Fig. 6. Impact resistance with curing age of reference and ECC concrete mixes containing IL.

According to the test results shown in Table XI and Figures 5 and 6 , the samples reinforced with steel mesh and PP fibers have the greatest results with 67,93 , and 118 blows at 28,56 , and 90 days of water curing respectively, unlike the conventional mix which showed the lowest results. The mix reinforced with a plastic mesh had mid-values of 32, 50, and 67 blows respectively. The impact resistance test results interpretation is again divided into three stages:

At first, the addition of PP fibers: these fibers incorporated with the cement paste, enhanced the ability of micro cracks to spread without breaking or pulling the fibers and therefore the cracks in concrete were reduced.

The addition of small amounts of water-soluble polymers (PVA solution): enhances the bonding strength and durability of cementing materials.

The presence of steel mesh that has higher tensile strength: The bonding between concrete and reinforcing mesh plays a major role in impact resistance, as the number of blows required to cause first crack and failure increases. This can be attributed to the effect of the reinforcement mesh which helped absorb more impact energy efficiently (Figures 7-9). The behavior of superplasticized concrete slabs reinforced with different types of polymer grids and subjected to low velocity impact loading was studied extensively in [17]. The tested $500 \times 500 \times 50 \mathrm{~mm}$ and $500 \times 500 \times 25 \mathrm{~mm}$ slabs had either imported or local polymer grids. The adopted falling steel mass was $3.36 \mathrm{~kg}$ in weight and $9.5 \mathrm{~cm}$ in diameter and the falling height was $1.2 \mathrm{~m}$. Three mixes were used. Many properties were tested during this research, including compressive strength and impact resistance. The test results indicated that the presence of polymer grids as concrete reinforcement enhances significantly the mechanical properties of concrete. It increases the number of blows required to cause impact failure and delays first crack and final scabbing and spalling to take place [17]. 

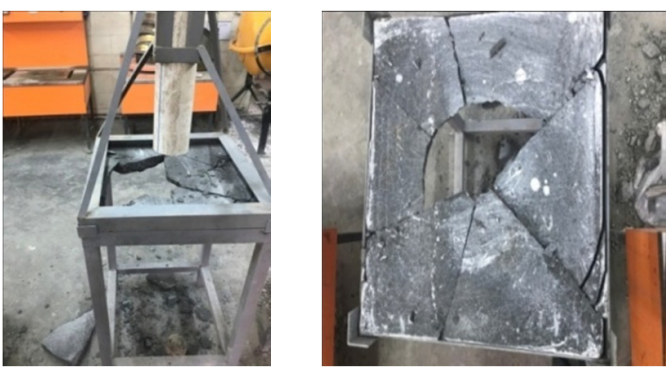

Fig. 7. Typical failure behavior of reference concrete specimens under impact.
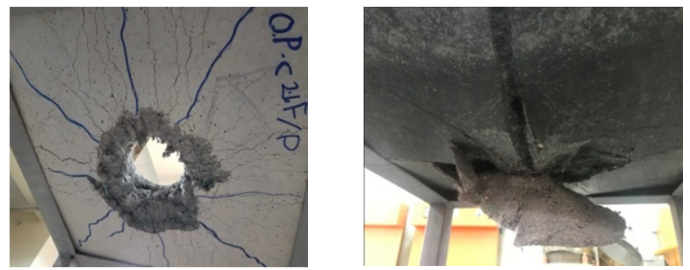

Fig. 8. Typical failure behavior of concrete specimens including 2\% PP fibers and polymer grids under impact.

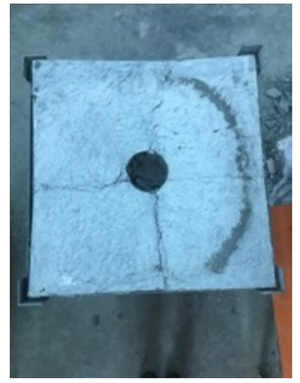

Fig. 9. Typical failure behavior of concrete specimens including 2\% PP fibers and steel grids under impact.

\section{CONCLUSIONS}

According to the obtained experimental results, the following are the most notable outcomes of the current study:

- Compressive strength increased by $36.11 \%, 45.5 \%$, and $52.4 \%$ over the traditional mixture at the age of 28,56 , and 90 days of water curing respectively.

- The fiber-reinforced slab and steel mesh showed superior performance in impact resistance compared to the traditional mixture and required 67,93 , and 118 blows at 28,56 , and 90 days respectively, while the slab reinforced with fiber and polymer mesh showed satisfactory results compared to the traditional mixture with 32,50 , and 67 respectively.

- The cost of bendable concrete was reduced by using IL cement.

- Bendable concrete made with locally available materials and reinforcements can be widely used instead of conventional concrete at complex construction sites.

- It is possible to use locally manufactured IL cement in producing bendable concrete with acceptable mechanical properties reinforced with locally available grids.

\section{REFERENCES}

[1] M. T. Lakhiar, S. Sohu, I. A. Bhatti, N. Bhatti, S. A. Abbasi, and M. Tarique, "Flexural Performance of Concrete Reinforced by Plastic Fibers," Engineering, Technology \& Applied Science Research, vol. 8, no. 3, pp. 3041-3043, Jun. 2018, https://doi.org/10.48084/etasr.2084.

[2] M. T. Lakhiar, N. Mohamad, M. a. B. Shaikh, A. A. Vighio, A. A. Jhatial, and A. A. A. Samad, "Effect of River Indus Sand on Concrete Tensile Strength," Engineering, Technology \& Applied Science Research, vol. 8, no. 2, pp. 2796-2798, Apr. 2018, https://doi.org/ 10.48084/etasr.1869.

[3] A. S. Buller, A. M. Buller, T. Ali, Z. A. Tunio, S. Shabbir, and M. A. Malik, "Experimental Characterization of Bacterial Concrete Against Mechanical and Durability Performance," Engineering, Technology \& Applied Science Research, vol. 11, no. 1, pp. 6703-6707, Feb. 2021, https://doi.org/10.48084/etasr.3983.

[4] V. C. Li, "On Engineered Cementitious Composites (ECC) A Review of the Material and Its Applications," Journal of Advanced Concrete Technology, vol. 1, no. 3, pp. 215-230, Jun. 2011.

[5] P. Archana, A. N. Nayak, S. R. Nayak, H. Vaddar, and D. S. Magnur, "Study of Strength of Polypropylene Fiber Reinforced Concrete," International Journal of Engineering Research \& Technology, vol. 6, no. 6, May 2017.

[6] K. Ramasamy, S. Kandasamy, and K. Mani, "Influence of polymeric and non-polymeric fibers in hybrid engineered cementitious composites," Romanian Journal of Materials, vol. 48, no. 4, pp. 507-513, Jan. 2018.

[7] A. Chaudhary and A. K. Sharma, "Experimental Study on Flexural Behaviour of Engineering Cementitious Composite as Bendable Concrete," International Journal for Research in Applied Science and Engineering Technology, vol. 7, no. 6, pp. 1274-1278, Jun. 2019 , https://doi.org/10.22214/ijraset.2019.6219.

[8] V. C. Li, "Strategies for High Performance Fiber Reinforced Cementitious Composites Development," in Proceedings of International Workshop on Advances in Fiber Reinforced Concrete, Bergamo, Italy, Sep. 2004.

[9] Cement-Part 1: Composition, specifications and conformity criteria fo rcommon cements. CEN, 2011.

[10] Iraqi Specification, No. 45 Aggregate from Natural Sources for Concrete and Construction. Baghdad, Iraq, 1984.

[11] C09 Committee, "ASTM C1240 - 03a: Specification for Silica Fume Used in Cementitious Mixtures," West Conshohocken, PA: ASTM International. https://doi.org/10.1520/C1240-03A.

[12] ASTM C494 / C494M-15, Standard Specification for Chemical Admixtures for Concrete. West Conshohocken, PA: ASTM International, 2015.

[13] Iraqi Specification, No .1703: Water used in concrete. Baghdad, Iraq: Central Organization for Standardization and Quality Control, 1992.

[14] "Testing concrete — Part 116: Method for determination of compressive strength of concrete cubes," in British Standard, BSI, 1983.

[15] S. S. Saeed, "Time-dependent deformation behavior of bendable concrete produced by Portland limestone cement," M.S. thesis, University of Baghdad, Baghdad, Iraq, 2016.

[16] ACI Committee 544, "Design Considerations for Steel Fiber Reinforced Concrete," ACI, West Conshohocken, PA, USA, ACI 544.4R-88, 1988.

[17] I. F. A. Almulla, "Behaviour of concrete units containing Polymer grids'," M.S. thesis, University of Baghdad, Baghdad, Iraq, 2002. 